\title{
REGIONAL WATER SECURITY IN THE HINDU KUSH HIMALAYAN REGION: ROLE OF GEOSPATIAL SCIENCE AND TOOLS
}

\author{
Shahriar M Wahid, ${ }^{\mathrm{a},}$, Arun B. Shrestha ${ }^{\mathrm{a}}$, M.S.R. Murthy ${ }^{\mathrm{a}}$, Mir Matin ${ }^{\mathrm{a}}$ Jianqiang Zhang ${ }^{\mathrm{ab}}$ and Omaid Siddiqui ${ }^{\mathrm{a}}$ \\ a International Center for Integrated Mountain Development, Lalitpur, Kathmandu, Nepal, Email: Shahriar.Wahid@icimod.org \\ ${ }^{\mathrm{b}}$ Chinese Academy of Sciences (CAS), China
}

\section{Commission TC VIII}

KEY WORDS: Hindu Kush Himalayan river basins, Water resources assessment, Disaster risk reduction

\begin{abstract}
:
The Hindu Kush Himalayan (HKH) region is the source of ten large Asian river systems - the Amu Darya, Indus, Ganges, Brahmaputra (Yarlungtsanpo), Irrawaddy, Salween (Nu), Mekong (Lancang), Yangtse (Jinsha), Yellow River (Huanghe), and Tarim (Dayan), - and provides water, ecosystem services, and the basis for livelihoods to a population of around 0.2 billion people in the region. The river basins of these rivers provide water to 1.3 billion people, a fifth of the world's population. Against this background, a comprehensive river basin program having current focus on the Koshi and Indus basins is launched at the International Center for Integrated Mountain Development (ICIMOD) as a joint scientific endeavour of several participating institutions from four regional countries of the HKH region. The river basin approach aims is to maximize the economic and social benefits derived from water resources in an equitable manner while conserving and, where necessary, restoring freshwater ecosystems, and improved understanding of upstream-downstream linkages. In order to effectively support river basin management satellite based multi sensor and multi temporal data is used to understand diverse river basin related aspects. We present here our recent experiences and results on satellite based rainfall and run off assessments, land use and land cover change and erosion dynamics, multi thematic water vulnerability assessments, space based data streaming systems for dynamic hydrological modelling, and potential applications of agent based models in effective local water use management.
\end{abstract}

\section{INTRODUCTION}

The Hindu Kush Himalayan (HKH) region is a vast complex of high mountains, intermountain valleys, and plateaus shared by Afghanistan, Bhutan, China, India, Nepal, Myanmar, and Pakistan (Tsering and Wahid 2011). It produces one of the world's largest renewable supplies of freshwater that is vital for the survival and well-being of billions of people and precious ecosystems in the river basins that stretches beyond the HKH region. With poverty affecting larger portion of burgeoning population, pressure on natural resources will increase, as will the demand for food, water and energy (ICIMOD 2011) leading to conflict in the region. The potential impacts of climate change is likely to accelerate the retreat of glaciers and change regional hydrological regime, increase the magnitude and frequency of natural disasters, reduce water availability during low flow periods and deteriorate water quality (Immerzeel 2011). Furthermore, changes in the major atmospheric circulation over the region are likely to impact the moisture regime and consequently the hydrological regime of the river basins (ICIMOD 2011). These changes are expected to accelerate in the coming decades with potentially profound and widespread effects on biodiversity conservation, water resources availability and access, and related livelihood and food security challenges.

Despite substantial economic growth over the past decade, transboundary water resources development and management in the region is still limited (Rahaman 2012) if compared with many large river basins around the world such as Murray Darling, Danube, Mekong, Nile and the Rhine. The governments of the HKH region are increasingly recognizing that sustainable development of the economic potential of the river systems for domestic use, fisheries, hydropower, navigation, irrigation, drought and flood management and ecosystem conservation can reduce poverty, improve livelihoods and promote sustainable development in the region (SAARC 2010).

The transboundary nature of water in the major HKH basins implies that equitable use of their water is often a source of tension and dispute and an issue of sovereignty and strategic necessity in the region. Past bilateral efforts have not been conducive to the balanced development of the resources, and have been source of antagonism between the riparian countries (Rahaman 2011). The nature of hydrological cycle determines water supply, which is variable in time, space, and quality, and its peaks usually do not coincide with the high demand periods. For example, Brahmaputra River is supplied mainly by monsoon rains; $80-85 \%$ of the total precipitation falls between June and September. At the slopes of the Himalayas, in the Brahmaputra source area, the annual precipitation is $5,000-10,000 \mathrm{~mm}$, while the mean annual evapotranspiration, although of course decreasing with increasing height, is 1,200-1,300 mm. The Ganges River is also supplied by monsoon rains and snow, though less intensive. The annual precipitation is $500-1,000 \mathrm{~mm}$, with some areas receiving as much as $2,000 \mathrm{~mm}$. Annual evapotranspiration is $1,400-1,800 \mathrm{~mm}$; less in the mountains. 
This, together with intensive use of the water resource, results in the flooding in some parts of the GBM Basin.

Again, large parts of the Ganges sub-basins in India and north-western part of GBM sub-basins in Bangladesh are vulnerable to drought. The principal cause of drought may be attributed to the erratic behavior of the southwest monsoon. The southwest monsoon denotes the rainfall received between the months of June and September and accounts for around $85 \%$ of the rainfall in the Ganga and Yamuna sub-basins of India. The average per capita water availability also illustrates considerable spatial variation.

The mitigation of problems associated with variability and uncertainty in supply present problems in specifying property rights and impedes efficient resource use by reducing the expected value of engaging in water-related activities. Since under conditions of uncertainty, deferred use does not guarantee future availability. Changes in the timing, location, quantity and quality due to water uses and other human activities in the upstream reaches usually directly or indirectly effects downstream water users. However, key questions arise about the wider perspective on water resources availability and management due to nonavailability for reliable monitoring and science-based assessment. This paper presents the issues and challenges of contemporary water resources management in the Himalayan river basins and discusses the changing waterscape in the HKH basins due to global environmental change. It further presents a number of geospatial science and tools application in water resources development and management including water related disaster risk management.

\section{THE CHANGING WATERSCAPE}

Global environmental changes in the mountains are responsible for unique changes in the cryosphere, climate and hydrology in the HKH basins. Bohner and Lehmkul (2005) estimated a $43-81 \%$ decline in the current coverage of Himalayan glaciers by 2100 . Sharma et al. (2009) have reported a temperature rise in the Eastern Himalaya region mainly in January, February and March (0.01-0.048C annually). They also project that by the middle of the century, mean temperature will increase by $2.98 \mathrm{C}$ by $2.9-$ $4.38 \mathrm{C}$ annually. Annual precipitation is also likely to increase by $18 \%$ by the middle of the century and $13-34 \%$ by the end of the century (Sharma et al 2009).

The impacts will be particularly significant in regions adjacent to the Himalayan Mountain (Barnett et al. 2005; Zemp and Haberli 2007). Alford et al. (2009) consider the impact of a $3^{\circ} \mathrm{C}$ increase in temperature, finding that this will reduce the volume of glaciers of Nepal Himalaya by an estimated $60 \%$ over the 21 st Century if there is no change in current precipitation patterns. It is suggested that the Himalayan river discharge is likely to increase for some time as a result of accelerated melting, but as glacier water storage capacity is reduced the flow is likely to decline (Eriksson et al. 2009). Based on current knowledge, the rivers most likely to experience the greatest loss in water availability in response to melting glaciers are the Indus, Tarim, Yangtze, Brahmaputra, and Amu Darya (Xu et al. 2009).

However, Cogley et al. (2010) claims that Himalayan glacier retreat and impacts on river flows have is a complicated and uncertain process and generally lacked a rigorous scientific basis, and have been seized upon by climate sceptics as showing doubt in the scientific evidence purported in the Fourth Assessment Report (AR4) of the United Nations Intergovernmental Panel on Climate Change (IPCC, 2007). In fact, the evidence on glacier shrinkage and the resulting impact on water availability are extremely limited, and there is no consistent proven body of evidence to suggest such claims (Miller et al. 2011). Some of the most advanced global hydrological models have been driven by ensembles of climate models (e.g. Arnell 2003; Nohara et al. 2006) to understand the resulting impacts upon river runoff. However, the resolution and uncertainty in regional climatic changes means that it is difficult to derive localized data on predicted changes to river discharges, and such models only attempt to determine spatial patterns of the effects of climate change, not magnitudes. Best interpolation of changes predicted by multiple climate models from figures provided by Arnell (2003) in the IPCC AR4 report suggest corroborated increases of runoff across the Himalaya, while changes in runoff from the Karakoram and Hindu-Kush are highly model-dependent.

Considerable material has been published on the topic of water availability from the mountainous regions of the Himalaya, including more systematic appraisals of the existing evidence, along with more rigorous scientific research. Immerzeel et al. (2010) predicted a 19.6\% decrease in flow from the upper Brahmaputra basin for the period 2046-2065. Hydrological modelling of the upper Indus basin using the Snowmelt Runoff Model (SRM) by Immerzeel et al. (2009) found that regional warming is affecting the melting of glaciers. Under SRES A2 scenario for 2071-2999, using PRECIS regional simulation output, with an assumed $50 \%$ decrease in glacier area, total glacier runoff reduces by $22 \%$, rain runoff increases by $53 \%$, and total runoff increases by $7 \%$. This has led to a far greater understanding of the physical patterns of change that are occurring within the region, and better predictive ability to assess the impacts of climate change on Himalayan hydrology.

\section{NEED FOR IMPROVED WATER ASSESSMENT AND DISASTER RISK REDUCTION}

In general there is a lack of reliable systematic monitoring and assessment of climate and hydrology in the region (Eriksson et.al. 2009) which reduces societal interest in devoting resources to respond and results in ad-hoc ambiguous actions. When changes are not steady-state and mired in uncertainties, it is difficult to respond in a way that 
catalyses action grounded on commitment. In addition, complex problems arise uncertainty related to global environmental change. Lack of understanding of vulnerability hinders the capacity to cope and adapt, or resilience. This goes beyond mapping the exposure zone that is actually witnessing direct impact from change, and encompass broader understanding of socio-cultural process of the society that underpin change, and capacities to cope. Hence, there is a need for more effective mechanisms to improve the assessment of water resources in the region. This would involve: region-wide long-term monitoring schemes of climate and water based on agreed cohesive set of indicators; implementation of regional climatic and water resources modelling; identification of hot spots or severelyaffected areas disasters such as flood prone areas, droughtprone areas, degraded areas etc.; and development of comprehensive knowledgebase to communicate the link between responding to environmental change and development planning and program.

\section{APPLICATION OF GEOSPATIAL SCIENCE AND TOOLS}

\subsection{Surface Water Extent Estimation}

Recognizing the lack of available in-situ measurement in the mountains, satellite based estimation is increasingly being used for surface water assessment including spatial and temporal variability in water storage, extent and river discharge. This has helped to overcome various data gaps in ungauged basins due to irregular availability of data, existence of missing data, and lack of quality control for observed data. Various optical and RADAR satellite systems have been deployed during last decades for assessing different aspect of surface water assessment (Alsdorf et al., 2007).

Surface water extent could be measured by optical imagery such as LandSAT, SPOT, IRS, MODIS and with RADAR imagery such as RADARSAT, JERS, ERS at different spatial and temporal resolutions (Alsdorf et al., 2007). Optical remote sensing are used for identifying extent of water bodies. Water has distinct reflectance characteristics from other land cover. It absorbs most of the energy in near infrared and mid infrared image bands while vegetation and soil has higher reflectance in these wave length. Though optical remote sensing could provide very accurate estimation of water extent based on the image resolution, their use is limited by their inability to penetrate cloud. The microwave sensors overcomes this limitation. Synthetic aperture Radar (SAR) images offers higher capability of surface water extent mapping during monsoon compared to optical images (Imhoff et al., 1987). The landcover dynamics, and flood inundations studies includes water as one of the critical feature for change assessment studies. The spatial and temporal changes in surface water in terms of river, lakes, wetlands, waterlogged areas have been mapped over 3 decades of time across different Himalayan countries (http://geoportal.icimod.org/Home/ScienceAppDetail?appi $\underline{\mathrm{d}=16}$ ).

\subsection{Assessment of Water Cycle Components}

For accurate assessment of water cycle and water balance, it is critical to estimate the state of each of the component of the cycle. Conventional methods of estimating various components of hydrological cycle from observed point data are generally not appropriate for Himalayan river basins with high spatial variability, particularly with respect to land cover and topography (Matin and Bourque, 2013b). Insufficient monitoring stations make it particularly difficult to estimate these variables that is spatially representative of large areas. Remote sensing offers great advancement either direct measurement of the parameters of water cycle or providing input to models for estimating these variables. Karimi et al (2014) have demonstrated new water accounting plus (WA+) framework in Indus basin of Himalayas using satellite derived estimates of land use, rainfall, evaporation (E), transpiration (T), interception (I) and biomass production. It shows how satellite-derived estimates compares with measured basin outflow and how the accounting results can be interpreted to identify existing issues such as depletion of water resources, storage change, land and water productivity and examine solutions for the future

4.2.1 Precipitation: Precipitation is the most important component of hydrological cycle (Shin et al., 2001; Su et al., 2008). Assessment of precipitation in the mountain and in the lower reaches is needed for management and conservation of soil-water in the watersheds (Cunjie et al., 2010). Precipitation measurement from remote sensing is indirect mainly modelled from remote measurement of related variables (Matin and Bourque, 2013c). Satellite rainfall estimation is based on differentiating precipitating clouds from the non-precipitating clouds by relating the brightness of the cloud to observed rainfall intensities (Alsdorf et al., 2007). In case of microwave remote sensing RADAR back scattering from cloud and rain are differentiated to estimate precipitation.

Various algorithms have been introduced in literature for estimating precipitation. Based on comparison of 50 precipitation algorithm with ground based observation and Doppler RADAR data, (Ebert and Manton, 1998) concluded that Satellite based estimation produce reasonable accuracy for instantaneous precipitation and higher accuracy when averaged over monthly time scale. Tropical Rainfall Measuring Mission (TRMM; i.e., product 3B43), available at $0.25^{\circ} \times 0.25^{\circ}$ spatial resolution $(\sim 26 \mathrm{~km} \times \sim 26 \mathrm{~km})$, provides one of the best possible satellite-based product of total precipitation at broad temporal scales (e.g., monthly or annually; (Huffman et al., 1997; Huffman et al., 2007; GCMD, 2010). For effective assessment of water resources and filling the data gaps in the Brahmaputra river basin, 
(Bajracharya et al., 2014) evaluated five satellite precipitation products i.e CPC-RFE 2.0, RFE 2.0-Modified, CMORPH, GSMaP and TRMM 3B42 (Huffman et al., 1997; Huffman et al., 2007) for their suitability for hydrological assessment at various temporal scale and concluded that RFE 2.0, RFE 2.0-Modified TRMM 3B42 could reasonably detect heavy and low rainfall but underestimated the magnitude in high mountainous area. Mandira et al (2011) verified GSMAP rainfall estimates over central Himalayas at two levels, firstly for the whole country and secondly for physiographic regions. Verification with physiographic regions show that the GSMaP_MVK+ performs well in flatter terrain with a correlation coefficient of higher than 0.8 and prediction accuracy of $70 \%$; however, performance deteriorates with increase in altitude. The results indicate the need for improvement of GSMaP_MVK+ estimates by considering orography in the algorithm or bias adjustment before application in the Himalayas. Duo et al(2012) reported that NOAA CPC RFE 2.0 products performed well in the estimation and monitoring of rainfall over the Tibet and can be used to analyze the precipitation pattern, produce discharge forecast, and delineate the flood hazard area.

4.2.2 Evapotranspiration (ET): Evapotranspiration represents the loss of water through direct soil water evaporation and vegetation transpiration (Patel et al., 2006). It is one of the key processes in the hydrological cycle (Matin and Bourque, 2013a). Assessment of the spatial and temporal variability of evapotranspiration is important to understand the water cycle, climate dynamics and terrestrial ecological processes (Luo et al., 2010) in order to manage water resources in the watersheds (Bastiaanssen et al., 2005). Due to lack of sufficient ground observation station, Satellite remote sensing has been considered the most useful tool for ET estimation (Luo et al., 2010).

ET Estimation based on satellite remote sensing data shown great potential for monitoring ET over a large area with high temporal frequency. Remote sensing based estimation of ET can be categorized into three main groups, i.e., methods based on: (i) the surface-energy balance equation (Bastianssen et al., 1998; Kustas and Norman, 1999; Su, 2002); (ii) Penman-Monteith and Priestley-Taylor equations (Penman, 1948, 1956; Priestley and Taylor, 1972); and (iii) the complementary relationship (Bouchet, 1963; Granger, 1989). All these methods require an assessment of available net energy at the surface as primary input but differ in the way they partition the energy into sensible and latent heat fluxes. A remote sensing-based approach for water accounting in the East Rapti River Basin, Nepal demonstrated a procedure for accurately generating evaporative depletion and runoff in mountainous areas using Landsat ETM+ images combined with standard hydrometeorological data (Rajendra et al 2011).

4.2.3 Water Level and Volume: Water level and discharge measurement of rivers and tributaries in the mountain region pose specific challenge. Satellite based water level estimate are based on SAR interferometric and radar altimetric measurements. Altimetric measurements are based on statistical profiling of measurements from surroundings of location and provides point based elevation while interferometric data provides gridded elevation measurements. Interferometric measurements are very incoherent over smooth surfaces like water bodies but could provide accurate elevation for vegetated water bodies (Alsdorf et al., 2000).

The remote sensing based altimetry application started in 1990 with the NASA Radar Altimeter operating on board of NASA's TOPEX/Poseidon satellite. The system could provide altimetric data for large water bodies and rivers greater than $1 \mathrm{~km}$ width with an accuracy of $11 \mathrm{~cm}$ RMS (Birkett, 1998). Other satellite altimetry sensors include ERS-2, Envisat, and Jason series. (Frappart et al., 2006) combined satellite altimetry data with water extent from optical imagery to calculate temporal variation of water volume in lower Mekong river basin. Similar methodology was applied by (Pandey et al., 2014) combining altimetry data from Envisat and optical data from MODIS to estimate water level in Koshi river basin during a flood event in 2008. While altimetric data provide very good indication of relative changes in water level, their absolute accuracy has large variation compared to in-situ observation and hydrodynamic model result. Siddique-E-Akbor et al. (2011) compared Envisat derived water level estimate with HECRAS simulated water levels at the four altimeter tracks over Ganges, Upper Meghna and Jamuna river of Bangladesh and found that Envisat estimates exceeded model based estimates by $0.20 \mathrm{~m}$ and $1.90 \mathrm{~m}$ for Monsoon and dry seasons, respectively. Hossain et al. (2014) showed that altimetry could successfully provide transboundary flow and used to forecast river water level in downstream location with 5-day or higher lead time.

\subsection{Crop Water Productivity (WP) Assessment}

Agriculture sector face constant pressure to improve its water productivity due to rapid population growth, increasing non-agricultural activities and climate warming. A particular case in point is the Koshi river basin which is home to more than 50 million people, with agriculture as their main source of livelihoods (Neupane et al, 2013). Rice is one of the major staple crop grown in the river basin, however, its productivity is too low as compared to South Asian and global average. Furthermore, rice yield significantly varies within the basin itself, especially in Bihar part. Therefore, a robust econometric and geospatial methods to measure rice water productivity, investigate patio-temporal variation and test the impact of various factors on water productivity is of utmost importance.

Geospatial techniques like climate surface generation and spatial linkages with different crop and socio-economics data of 11 districts has been used to measure the WP for the period of 1991-2010, and assess the variation of WP between 
the districts and seasons (Non-monsoon and Monsoon). Furthermore, the spatial regression analysis was carried out to evaluate the impact of different factors on WP. We found that the average annual rice WP and 'marginal physical productivity' (MPP) remained at $0.22 \mathrm{~kg} / \mathrm{m} 3$ and 249 gram $/ \mathrm{m} 3$. Also, considerable variation within the seasons and across the districts were observed. The impact of flood and drought, irrigation and cropping intensity were statistically significant.

Use of geospatial methods has helped to better understand the spatiotemporal variation of WP in the Koshi river districts of Bihar ultimately benefiting the farmers with information about the appropriate planting season. It provides empirical evidence for policy makers to prioritize water management to enhance the rice water productivity, as stated elsewhere (Cai and Sharma 2010, Singh et al (2008), Kishore, 2004, Ladha et al and 2003, Swaminathan 2003).

\subsection{Water Vulnerability Assessment}

Water vulnerability is one of the major challenges facing people in the HKH river basins, and expected to increase with climate and other change. In order to develop appropriate and effective adaptation strategies, it is necessary to understand the level and spatial distribution of water vulnerability and the underlying biophysical and socioeconomic factors. Neupane et al. (2013) adopted the UNEP water vulnerability assessment model (Babel and Wahid, 2009) to assess district level water vulnerability. The study used 34 variables (5 for resource stress, 6 for development pressure, 7 for ecological security, and 16 for management challenges).

The information needed to implement the vulnerability model was generated using both remotely sensed data of biophysical variables and ground measurement data on socio-economic and hydrology. The variables were integrated in geospatial domain with suitable weightage for different variables and the four components of the vulnerability to estimate district level vulnerability, understand component level contribution and identify suitable adaptation needs. The component-wise vulnerability assessment showed that mountain and mid-hill areas (upstream) are more vulnerable in terms of resource stress and ecological security, whereas the plains areas are more vulnerable in terms of development pressure, while all parts of the basin were vulnerable in terms of management capacity. Five districts were identified as hot spots of water vulnerability that need immediate attention to improve the situation.

Implementation of RS data and geospatial techqniques in this study is helping planned make adaptation plans based on location-specific vulnerability characteristics rather than using a blanket approach. The findings will help policy makers to identify the water vulnerable geographical zones and districts and to frame policy plans for these particular locations.

\subsection{Water Related Risk Assessment}

The Himalayan mountain ranges are young with fragile geology and seismic instability, steep slopes, and a variable climate marked by extreme weather events, intense seasonal precipitation, and long periods of drought (Slaymaker, 2010). All of these mean that geological and hydro meteorological hazards - earthquakes, floods, flash floods, landslides, debris flows, droughts, and wild fires - are a common feature of life, with impacts that extend from the high mountains to the plains. Added to these disaster risks, the sedimentation and erosion dynamics contribute to high vulnerability, induces land degradation and impacts productivity of the system(Dolan and Walker, 2006; Werner and McNamara, 2007).

The risk factors are increased by the effects of human activities such as deforestation, unplanned human settlement, extension of agriculture onto landslide prone areas, and badly engineered roads in the mountains and hills; and deforestation and vegetation loss (Alix-Garcia et al., 2008), poorly planned river training measures, and settlement in flood prone areas (Uddin et al., 2013; Uddin and Shrestha, 2011), in the plains. With the exception of earthquakes, most hazards in the region are water related (Keefer, 2000). For example, shifts in monsoon precipitation patterns may lead to an increase in the frequency and intensity of droughts and episodes of intense precipitation, which may in turn lead to increases in floods, landslides, and erosion (Ebi et al., 2006; Houghton et al., 2001).

Considering this severity, studies are initiated to enhance understanding of the disaster vulnerability and develop appropriate risk reduction and adaptation strategies. The geospatial data and models are effectively used in developing inventory and susceptibility assessment of landslides, spatial explicit estimation of soil erosion over the Koshi basin. Furthermore, studies are initiated to develop automated flood inundation assessments, drought forecasting and glacial lake outburst related risks using multi sensor satellite data, related conjunctive ground measurement and knowledge.

4.5.1 Soil Erosion Assessments: The lack of comprehensive data and knowledge on erosion and sedimentation dynamics and underlying processes in the Himalayas has been highlighted by various studies. In particular, there seems to be a lack of a good understanding of the spatial and temporal dynamics of erosion and sedimentation, including causes and effects, in the upstream-downstream context of the Himalayas. This also applies to the Koshi river basin, where studies and research have been scattered and there are no data for the entire basin. The studies conducted on erosion assessment either using field or model based methods has reported high erosion rates in middle mountains of Nepal 
where erosion susceptible part of Koshi basin exists (Ramsay, 1987). Lack of data hinders estimation of the current and future movements of sediment loads, their spatio temporal behavior, and impacts at the basin scale.

To address these gaps, the Koshi Basin Programme has initiated research into the erosion and sedimentation processes in the basin with the aim of assessing the status and trends in land use/land cover change, hydro-geomorphic change, erosion and sedimentation processes and their interdependencies, and drivers and impacts in the basin. Spatial soil erosion assessment over Koshi basin was done using Revised Universal Soil Loss Equation (RUSLE).The rainfall, land cover, soil and topography information in spatial domain was used as primary data inputs. Based on this rainfall erosivity, soil erodability, slope length factor, crop management factor and Support Practice factor information were generated empirically either by local ground specific information or using most suitable published literature to estimate soil erosion through RSLUE method. In the present study we have chosen optimal equations and weightage factors based on published 24 field erosion experimental plot data and 12 model based erosion studies pertaining to middle mountains of Nepal. The primary information layers on rainfall, soil, land cover and topography were partly generated in house and also developed through integration of different sources of information.

The RUSLE was implemented in ARC GIS to bring spatial estimates of erosion. The average erosion levels across different land cover classes are estimated with a range of $0.05-100 \mathrm{t} / \mathrm{ha} / \mathrm{annum}$. The average erosion at basin level is estimated at $6.8 \mathrm{t} / \mathrm{ha} /$ year. The middle mountains were reported to have erosion rates at 14-16 t/ha/year. Spatially the erosion patterns were grouped in to 8 classes and their distribution across different land cover classes and elevation ranges was assessed. Grasslands and agriculture were found with high proportion of higher erosion classes. The erosion estimates made were found within the ranges of reported levels of erosion from plot level measurements and model estimates. The study also highlights the importance of geospatial tools and techniques to understand the spatial nature of erosion for river basin management.

4.5.2 Landslide assessment: Landslide as a natural slope mass movement is very common in mountainous areas, which occupy $24 \%$ of the global land surface area and are home to $12 \%$ of the world's population (Schild, 2008). Massive losses in casualty and property will occur if landslide mass movement and deposition engages human activities. It is widely observed that many a catastrophe have been caused by landslides from time to time, especially under the background of extreme weather increase and climate change.

Field landslide investigation is a time-consuming and strenuous work in the vast mountain regions, and remains confined along roads or rivers. Remote Sensing technology is utilized in landslide interpretation for fast data acquisition over large basin area and to reduce labor and time cost. The accuracy of landslide interpretation becomes higher with the development of high resolution remote sensing images. In recent years, global free sources of high resolution remote sensing images, such as Google Earth and ArcGIS Basemap allows landslide interpretation for large area. Based on the investigation of landslides, the relationships between landslide and causative factors, such as geologic factors, topographic factors, and climate factors, can be analyzed by Geographical information technology, statistical or data mining methods. Susceptibility model can be built to assess the stability of slopes and landslides prone areas. Furthermore, landslide risk assessment can be carried out to locate vulnerable settlements, roads or farmlands.

For example, a total of 3,398 landslides are interpreted by Google Earth and ArcGIS Basemap in the Koshi river basin. These landslides concentrate on two areas: Siwalik and Middle mountain area, where precipitations are very high during monsoon. Precipitation, topography and geology influence the occurrence of landslides synthetically. Strata are fragile in Siwalik area, because three faults pass through this area. But most of landslides in this area are small or medium scale. The slopes are steep in Middle mountain area, and the topography provides enough potential energy for landslides. Many medium and large scale landslides distribute in this area. The outcomes of landslides investigation, susceptibility assessment and risk assessment by utilize of Geospatial technologies can support landslides disaster prevention and risk control for governments.

\section{CONCLUSION}

The overwhelming complexity of interactions between global and regional change and water management in the HKH regions and social-environmental response calls for increased linking of expanded scientific research and knowledge to support policy formulation. Future policy must anticipate these interactions by promoting long-term monitoring and data collection on climate and hydrology; and closing knowledge gaps through substantiated studies of water-food-energy nexus in river basins. However, longterm monitoring, data collection and basin-wide resource assessment in the HKH region has proved to be challenging due to inherent resource setting harshness (e.g. high mountain water towers) and transboundary management regime. To address these issues, geospatial science and tools have been successfully applied to implement regional climatic and water resources models and develop assessment to support river basin management, policy planning and monitoring; identification of hot spots or severely-affected areas in terms of water related disaster vulnerability, drought-prone areas, water stressed areas, degraded areas etc. These application has supported regional comprehensive knowledgebase to communicate the link between responding to change and development planning and programming. It is hoped that intra-regional sharing and 
transfer of technology and capacity development of existing and new institutions for research and assessment will further strengthen the use of geospatial science and tools in river basin management.

\section{ACKNOWLEDGEMENT}

This paper was prepared under the Koshi Basin Programme at the International Centre for Integrated Mountain Development (ICIMOD), which is supported by the Australian Government through the Sustainable Development Investment Portfolio (SDIP) for South Asia.

\section{REFERENCES}

Alford, R.A., Bradfield, K.S., Richards, S.J., 2007. Ecology: Global warming and amphibian losses. Nature 447, E3-E4.

Alix-Garcia, J., De Janvry, A., Sadoulet, E., 2008. The role of deforestation risk and calibrated compensation in designing payments for environmental services. Environment and Development Economics 13, 375-394.

Alsdorf, D.E., Melack, J.M., Dunne, T., Mertes, L.A.K., Hess, L.L., Smith, L.C., 2000. Interferometric radar measurements of water level changes on the Amazon flood plain. Nature 404, 174-177.

Alsdorf, D.E., Rodriguez, E., Lettenmaier, D.P., 2007. Measuring surface water from space. Rev Geophys 45.

Arnell, N.W., van Vuuren, D.P., Isaac, M., 2011. The implications of climate policy for the impacts of climate change on global water resources. Global Environmental Change 21, 592-603.

Babel, M.S., Wahid, S.M., 2009. Freshwater under threat: South Asia-vulnerability assessment of freshwater resources to environmental change. United Nations Environment Programme and Asian Institute of Technology, Bangkok.

Bajracharya, S., Palash, W., Shrestha, M., Khadgi, V.R., Duo, C., Das, P., Dorji, C., 2014. Systematic evaluation of satellite-based rainfall products over the Brahmaputra basin for hydrological applications. Advances in Meteorology, Accepted for publication.

Bajracharya, S.R., Mool, P., 2010. Glaciers, glacial lakes and glacial lake outburst floods in the Mount Everest region, Nepal. Annals of Glaciology 50, 81-86.

Barnett, T.P., Adam, J.C., Lettenmaier, D.P., 2005. Potential impacts of a warming climate on water availability in snowdominated regions. Nature 438, 303-309.

Bastiaanssen, W.G.M., Noordman, E.J.M., Pelgrum, H., Davids, G., Thoreson, B.P., Allen, R.G., 2005. SEBAL model with remotely sensed data to improve water-resources management under actual field conditions. Journal of Irrigation and Drainage Engineering-ASCE 131, 85-93.

Bastianssen, W.G.M., Menenti, M., Holtslag, A.A.M., 1998. A remote sensing surface energy balance algorithm for land (SEBAL). 1. Formulation. J Hydrol 212-213, 198-212.

Birkett, C.M., 1998. Contribution of the TOPEX NASA radar altimeter to the global monitoring of large rivers and wetlands. Water Resour Res 34, 1223-1239.

Böhner, J., Lehmkuhl, F., 2005. Environmental change modelling for Central and High Asia: Pleistocene, present and future scenarios. Boreas 34, 220-231.

Bouchet, R.J., 1963. Evapotranspiration réelle et potentielle, signification climatique, International Association of Hydrological Sciences, Proceedings of General Assmbly. California Symposium Publication, Berkely, California, pp. 132-142.

Casassa, G., López, P., Pouyaud, B., Escobar, F., 2009. Detection of changes in glacial run-off in alpine basins: examples from North America, the Alps, central Asia and the Andes. Hydrological Processes 23, 31-41.

Cogley, J.G., Kargel, J.S., Kaser, G., Van der Veen, C., 2010. Tracking the source of glacier misinformation. Science 327, 522.

Collins, A.B., Heupel, M.R., Simpfendorfer, C.A., 2008. Spatial distribution and long-term movement patterns of cownose rays Rhinoptera bonasus within an estuarine river. Estuaries and Coasts 31, 1174-1183.

Cunjie, Z., Bourque, C.P.-A., Landong, S., Hassan, Q.K., 2010. Spatiotemporal Modeling of Monthly Precipitation in the Upper Shiyang River Watershed in West Central Gansu, Northwest China. Advances in Atmospheric Sciences 27, 185 - 194.

DFID, 2006. Eliminating World Poverty: making governance work for the poor. International Development White Paper.

, TSO, London. Para 1.19.

Dolan, A., Walker, I., 2006. Understanding vulnerability of coastal communities to climate change related risks. Journal of Coastal Research, 1316-1323.

Ebert, E.E., Manton, M.J., 1998. Performance of satellite rainfall estimation algorithms during TOGA COARE. Journal of the Atmospheric Sciences 55, 1537-1557.

Ebi, K.L., Mills, D.M., Smith, J.B., Grambsch, A., 2006. Climate change and human health impacts in the United States: an update on the results of the US national assessment. Environmental health perspectives, 1318-1324.

Eriksson, M., Jianchu, X., Shrestha, A.B., Vaidya, R.A., Nepal, S., Sandström, K., 2009. The changing Himalayas: 
impact of climate change on water resources and livelihoods in the greater Himalayas. International centre for integrated mountain development (ICIMOD).

Frappart, F., Minh, K.D., L'Hermitte, J., Cazenave, A., Ramillien, G., Le Toan, T., Mognard-Campbell, N., 2006. Water volume change in the lower Mekong from satellite altimetry and imagery data. Geophysical Journal International 167, 570-584.

GCMD, 2010. TRMM and other sources rainfall product (TRMM Product 3B43), Federal Geographic Data Committee (FGDC) Metadata. NASA Global Change Master Directory, Lanham, MD, USA.

Granger, R.J., 1989. A complementary relationship approach for evaporation from nonsaturated surfaces. J Hydrol 111, 31-38.

Hossain, F., Siddique-E-Akbor, A.H., Mazumder, L.C., ShahNewaz, S.M., Biancamaria, S., Lee, H., Shum, C.K., 2014. Proof of Concept of an Altimeter-Based River Forecasting System for Transboundary Flow Inside Bangladesh. Ieee J-Stars 7, 587-601.

Houghton, J.T., Ding, Y., Griggs, D.J., Noguer, M., van der Linden, P.J., Dai, X., Maskell, K., Johnson, C., 2001. Climate change 2001: the scientific basis. Cambridge university press Cambridge.

Huffman, G.J., Adler, R.F., Arkin, P., Chang, A., Ferraro, R., Gruber, A., Janowiak, J., McNab, A., Rudolf, B., Schneider, U., 1997. The Global Precipitation Climatology Project (GPCP) combined precipitation dataset. Bulletin of the American Meteorological Society 78, 5-20.

Huffman, G.J., Adler, R.F., Bolvin, D.T., Gu, G.J., Nelkin, E.J., Bowman, K.P., Hong, Y., Stocker, E.F., Wolff, D.B., 2007. The TRMM multisatellite precipitation analysis (TMPA): quasi-global, multiyear, combined-sensor precipitation estimates at fine scales. Journal of Hydrometeorology 8, 38-55.

Imhoff, M.L., Vermillion, C., Story, M.H., Choudhury, A.M., Gafoor, A., Polcyn, F., 1987. Monsoon Flood Boundary Delineation and Damage Assessment Using Space Borne Imaging Radar and Landsat Data. Photogramm Eng Rem S 53, 405-413.

Immerzeel, W., Pellicciotti, F., Bierkens, M., 2013. Rising river flows throughout the twenty-first century in two Himalayan glacierized watersheds. Nature Geoscience 6, $742-745$.

Karimi, P., Bastiaanssen, W.G.M., Molden, D., Cheema, M.J.M., 2013. Basin-wide water accounting based on remote sensing data: an application for the Indus Basin. Hydrol Earth Syst Sc 17, 2473-2486.

Karimi, P., Bastiaanssen, W.G.M., Molden, D., Cheema, M.J.M., 2013. Basin-wide water accounting based on remote sensing data: an application for the Indus Basin. Hydrol. Earth Syst. Sci. 17, 2473-2486.

Kaser, G., Cogley, J., Dyurgerov, M., Meier, M., Ohmura, A., 2006. Mass balance of glaciers and ice caps: consensus estimates for 1961-2004. Geophysical Research Letters 33.

Keefer, D.K., 2000. Statistical analysis of an earthquakeinduced landslide distribution - the 1989 Loma Prieta, California event. Engineering Geology 58, 231-249.

Kustas, W.P., Norman, J.M., 1999. Evaluation of soil and vegetation heat flux predictions using a simple two-source model with radiometric temperatures for partial canopy cover. Agricultural and Forest Meteorology 94, 13-29.

Lemke, P, 2007. Observations: Changes in snow, ice and frozen ground, in Climate Change 2007: The Scientific Basis: Contribution of Working Group I to the Fourth Assessment Report of the Intergovernmental Panel on Climate Change. Cambridge Univ. Press, , New York.

Liniger, H., Gikonyo, J., Kiteme, B., Wiesmann, U., 2005. Assessing and Managing Scarce Tropical Mountain Water Resources: The Case of Mount Kenya and the Semiarid Upper Ewaso Ng'iro Basin. Mountain Research and Development 25, 163-173.

Luo, X., Wang, K., Jiang, H., Sun, J., Xu, J., Zhu, Q., Li, Z., 2010. Advances in research of land surface evapotranspiration at home and abroad. Sciences in Cold and Arid Regions 2, 104-111.

Matin, M.A., Bourque, C.P.-A., 2013a. Influence of vegetation cover on regional evapotranspiration in semi-arid watersheds in Northwest China, in: Alexandris, S.G. (Ed.), Evapotranspiration - An Overview. IntechOpen: available online:

http://www.intechopen.com/books/evapotranspiration-anoverview/influence-of-vegetation-cover-on-regionalevapotranspiration-in-semi-arid-watersheds-in-northwestch.

Matin, M.A., Bourque, C.P.A., 2013b. Assessing spatiotemporal variation in actual evapotranspiration for semi-arid watersheds in northwest China: Evaluation of two complementary-based methods. J Hydrol 486, 455-465.

Matin, M.A., Bourque, C.P.A., 2013c. Intra- and interannual variations in snow-water storage in data sparse desert-mountain regions assessed from remote sensing. Remote Sens Environ 139, 18-34.

Molden, D., Sakthivadivel, R., 1999. Water Accounting to Assess Use and Productivity of Water. International Journal of Water Resources Development 15, 55-71.

Neupane, N., Murthy, M.S.R., Rasul, G., Wahid, S., Shrestha, A.B., Uddin, K., 2013. Integrated Biophysical and 
Socioeconomic Model for Adaptation to Climate Change for Agriculture and Water in the Koshi Basin.

Nohara, D., Kitoh, A., Hosaka, M., Oki, T., 2006. Impact of climate change on river discharge projected by multimodel ensemble. Journal of Hydrometeorology 7, 1076-1089.

Pandey, R.K., Cretaux, J.F., Berge-Nguyen, M., Tiwari, V.M., Drolon, V., Papa, F., Calmant, S., 2014. Water level estimation by remote sensing for the 2008 flooding of the Kosi River. Int J Remote Sens 35, 424-440.

Papola, T.S., 2000. Women entrepreneurs in mountain areas. International Centre for Integrated Mountain Development (ICIMOD).

Patel, N.R., Rakhesh, D., Mohammed, A.J., 2006. Mapping of regional evapotranspiration in wheat using Terra/MODIS satellite data. Hydrological Sciences Journal-Journal Des Sciences Hydrologiques 51, 325-335.

Penman, H.L., 1948. Natural evaporation from open water, bare soil and grass. Proceedings of the Royal Society of London. Series A, Mathematical and Physical Sciences 193, 120-145.

Penman, H.L., 1956. Evaporation: an introductory survey. Netherland Journal of Agricultural Science 4, 9-29.

Prendergast-Miller, M.T., Duvall, M., Sohi, S.P., 2011. Localisation of nitrate in the rhizosphere of biocharamended soils. Soil Biology and Biochemistry 43, 22432246.

Priestley, C.H.B., Taylor, R.J., 1972. On the assessment of surface heat flux and evaporation using large-scale parameters. Mon Weather Rev 100.

Rahaman, M.M., Varis, O., 2009. Integrated water management of the Brahmaputra basin: Perspectives and hope for regional development, Natural Resources Forum. Wiley Online Library, pp. 60-75.

Ramsay, W., 1987. Sediment production and transport.in the Phewa Valley, Nepal. Proc. Int. Symp. on Erosion and Sedimentation in the Pacific Rim (Corvallis, Oregon, August 1987). IAHS (in press).

Ravallion, M., Chen, S., Sangraula, P., 2007. New evidence on the urbanization of global poverty. Population and Development Review 33, 667-701.

SAARC, 2010. Summit Declaration, 16 SAARC Summit 28-29 April 2010, Thimpu, Bhutan (available online: http://www.saarc-sec.org/userfiles/16thSummitDeclaration29April10.pdf)

Sagar, B., Mandira, S., others, 2011. Validation of the satellite-derived rainfall estimates over the Tibet. Acta Meteorol. Sin. 25, 734-741.
Schild, A., 2008. ICIMOD's position on climate change and mountain systems: The case of the Hindu Kush-Himalayas. Mountain Research and Development 28, 328-331.

Sharma, E., 2009. Climate change impacts and vulnerability in the Eastern Himalayas. International centre for integrated mountain development (ICIMOD).

Shilpakar, R.L., Bastiaanssen, W.G., Molden, D.J., 2011. A remote sensing-based approach for water accounting in the East Rapti River Basin, Nepal. Himal. J. Sci. 7, 15-30.

Shin, D.B., Chiu, L.S., Kafatos, M., 2001. Comparison of the monthly precipitation derived from the TRMM satellite. Geophysical Research Letters 28, 795-798.

Shrestha, M.S., Takara, K., Kubota, T., Bajracharya, S.R., 2011. Verification of GSMaP rainfall estimates over the central Himalayas. Ann J Hydraul. Eng JSCE 55, 37-42.

Siddique-E-Akbor, A.H.M., Hossain, F., Lee, H., Shum, C.K., 2011. Inter-comparison study of water level estimates derived from hydrodynamic-hydrologic model and satellite altimetry for a complex deltaic environment. Remote Sens Environ 115, 1522-1531.

Slaymaker, O., 2010. 4 Mountain hazards. Geomorphological Hazards and Disaster Prevention, 33.

Solomon, S., Qin, D., Manning, M., Chen, Z., Marquis, M., Averyt, K., Tignor, M., Miller, H., 2007. IPCC, 2007: climate change 2007: the physical science basis. Contribution of Working Group I to the fourth assessment report of the Intergovernmental Panel on Climate Change.

Su, F.G., Hong, Y., Lettenmaier, D.P., 2008. Evaluation of TRMM Multisatellite Precipitation Analysis (TMPA) and its utility in hydrologic prediction in the La Plata Basin. Journal of Hydrometeorology 9, 622-640.

$\mathrm{Su}, \mathrm{Z} ., 2002$. The surface energy balance system (SEBS) for estimation of turbulent heat fluxes. Hydrol Earth Syst Sc 6, 85-99.

Tsering, D., Wahid, S., 2011. A more integration approach to biodiversity conservation in the Hindu Kush-Himalayas, Umwelt und gesellschaft im einklang. Festschrift fur willi zimmermann, pp 267-277. Zurich: Dike Verlag AG

Uddin, K., Gurung, D.R., Giriraj, A., Shrestha, B., 2013. Application of Remote Sensing and GIS for Flood Hazard Management: A Case Study from Sindh Province, Pakistan. American Journal of Geographic Information System 2, 1-5.

Uddin, K., Shrestha, B., 2011. Assessing flood and flood damage using Remote Sensing: a case study from Sunsari, Nepal, 4th International Conference on Water and Flood Management. IWFM, BUET, Dhaka. 
Uddin, K., Shrestha, B., Alam, M.S., 2011. Assessment of Morphological Changes and Vulnerability of River Bank Erosion alongside the River Jamuna Using Remote Sensing. Journal of Earth Science and Engineering 1, 30-35.

UNEP/GRID, 2010. Vital climate change graphics for Latin America and the Caribbean: Special edition for the COP16/CMP

Viviroli, D., Weingartner, R., 2004. The hydrological significance of mountains: from regional to global scale. Hydrology and Earth System Sciences Discussions 8, 10171030.

Wanchang, Z., Ogawa, K., Besheng, Y., Yamaguchi, Y., 2000. A monthly stream flow model for estimating the potential changes of river runoff on the projected global warming. Hydrological Processes 14, 1851-1868.

Werner, B., McNamara, D., 2007. Dynamics of coupled human-landscape systems. Geomorphology 91, 393-407.

Xu, J., Grumbine, R.E., Shrestha, A., Eriksson, M., Yang, X., Wang, Y., Wilkes, A., 2009. The melting Himalayas: cascading effects of climate change on water, biodiversity, and livelihoods. Conservation Biology 23, 520-530.

Zemp, M., Armstrong, R., Gärtner-Roer, I., Haeberli, W., Hoelzle, M., Kääb, A., Kargel, J.S., Khalsa, S.J.S., Leonard, G.J., Paul, F., 2014. Introduction: Global Glacier Monitoring-a Long-Term Task Integrating in Situ Observations and Remote Sensing, Global Land Ice Measurements from Space. Springer, pp. 1-21. 